\title{
Application of Fullerton test in assessment of the influence of movement rehabilitation on the overall physical fitness of patients with lung cancer
}

\author{
Aleksander Barinow-Wojewódzki ${ }^{1}$, Maria Laurentowska1, Katarzyna Domaszewska², Edyta Michalak², \\ Katarzyna Paszkiewicz ${ }^{1}$
}

${ }^{1}$ Respiratory Disease Rehabilitation Centre (ZRCUO) of the University School of Physical Education in Poznań, Wielkopolskie Centre of Pulmonology and Thoracosurgery in Poznań

2Physiology Department of University School of Physical Education in Poznań

Kardiochirurgia i Torakochirurgia Polska 2013; 10 (4): 430-434

\begin{abstract}
Background: In recent years, lung cancer has been the cause of around 1.1 million deaths worldwide. The pathological changes occurring in the lungs lead to disorders of airflow in pulmonary alveoli with different levels of intensity. The disorders of ventilation and gas exchange cause respiratory acidosis and are directly responsible for the decrease of the physical capability of the body.

The aim of the paper was to evaluate the influence of different rehabilitation programs on the general physical fitness of patients under chemotherapy.

Material and methods: The study involved 70 men of mean age 63 . Before and after the rehabilitation, the physical fitness was evaluated using the Fullerton test. Three study groups were isolated, each of them involving a different level of intensity of rehabilitation.

Results: In the first group there was in increase of muscle strength and of the flexibility of the upper limbs. The strength of the lower limbs did not change and in the test after the therapy the length of the covered distance got shorter. With the second group, the strength and flexibility of both upper and lower limbs increased, as did the covered distance. No significant changes in the values of the parameters noted before and after the therapy were noted.

Conclusions: The program involving therapeutic exercises gave better results in the monitored parameters compared to rehabilitation treatment extended by endurance training. Key words: rehabilitation, lung cancer, Fullerton test.
\end{abstract}

\section{Streszczenie}

Wstęp: W ostatnich latach rak płuc był przyczyną ok. 1,1 mln zgonów na świecie. Pojawiające się w jego przebiegu zmiany patologiczne w płucach doprowadzają do zaburzeń przepływu powietrza w pęcherzykach płucnych o różnym stopniu nasilenia. Skutkiem tych nieprawidłowości jest nadmierne obciążenie pracą całego układu oddechowego, z mięśniami oddechowymi włącznie. Zakłócenia wentylacji i wymiany gazowej prowadzą do kwasicy oddechowej i bezpośrednio przyczyniają się do obniżenia poziomu wydolności fizycznej.

Celem pracy była ocena wpływu różnych programów rehabilitacyjnych na sprawność ogólną pacjentów chorych na raka płuc poddawanych chemioterapii.

Materiał i metody: Badaniami objęto 70 mężczyzn w wieku 63 lat. Przed rozpoczęciem i po ukończeniu leczenia rehabilitacyjnego oceniano sprawność pacjentów, posługując się testem Fullerton. Wyodrębniono 3 grupy badawcze, w których zastosowano rehabilitację o różnej intensywności.

Wyniki: Zastosowane leczenie rehabilitacyjne w grupie pierwszej spowodowało zwiększenie siły mięśniowej i elastyczności kończyn górnych, siła kończyn dolnych nie zmieniła się, zmniejszyła się długość dystansu w badaniu po terapii. W grupie drugiej wzrosła zarówno siła, jak i elastyczność kończyn górnych i dolnych oraz zwiększył się pokonany dystans. W grupie trzeciej nie stwierdzono istotnych różnic w wartościach badanych parametrów przed terapią i po niej.

Wnioski: Umiarkowany program rehabilitacyjny obejmujący ćwiczenia usprawniające spowodował uzyskanie lepszych wyników badanych parametrów w porównaniu z leczeniem rehabilitacyjnym poszerzonym o trening wytrzymałościowy.

Słowa kluczowe: rehabilitacja, rak płuc, test Fullerton.

Address for correspondence: dr Katarzyna Beata Domaszewska, University School of Physical Education, Królowej Jadwigii 27/39, 61-871 Poznań, Poland, phone: +48 501476 716, e-mail: kowalczyk@awf.poznan.pl 


\section{Introduction}

In recent years, neoplastic diseases - and lung cancer in particular - have been the cause of around 1.1 million deaths worldwide [1,2] and in the developed countries they have been the cause of death even two times more often [3]. Also, women die of lung neoplastic diseases three times less often than men [4].

The pathological changes occurring in the lungs lead to disorders of airflow in pulmonary alveoli with different levels of intensity $[5,6]$. The consequences of such abnormalities involve a very high strain for the whole respiratory system, including respiratory muscles $[7,8]$. The disorders of ventilation and gas exchange cause respiratory acidosis and are directly responsible for the decrease of the physical capability of the body.

Lung functioning disorders impact the cardiovascular system, causing the pressure level in the pulmonary artery system to rise, which consequently puts much strain on the right ventricle of the heart [9]. Blood coagulability of oncological patients is also impaired, which is an indirect cause of increase of resistance in blood vessels and of growth of pulmonary tension level [10]. Ventilation-circulatory disorders contribute substantially to the advancement of symptoms of physical effort intolerance [11].

The skeletal muscles appear to show an impaired ability of oxygen metabolism, which is manifested in lactic acidosis despite the proper functioning of lung ventilation [12].

The rehabilitation for oncological patients aims to prevent the continuous decrease in physical capability and at the same time is designed to increase the quality of im- munity of the organism in the struggle with lung cancer. The conducted study aimed to determine how much physiotherapy can improve the overall fitness of the patients.

\section{Material and methods}

The study involved 70 men in the age of $63.58 \pm 8.09$, all diagnosed with lung cancer according to WHO criteria from 1997. The patients underwent rehabilitation treatment in the Regional Specialist Hospital for Tuberculosis and Lung Diseases in Ludwikowo and a series of radiation therapy sessions in Greater Poland Cancer Centre. The observed patients did not differ much in terms of their age, height, body mass, BMI, the levels of doses of their therapeutic radiation and in terms of the length of stay in the hospital.

The groups included in the study are described in Table I, II and III.

The patients underwent the Fullerton test immediately before the commencement of rehabilitation treatment and immediately after the finish of the treatment. On the basis of the results achieved in the 6-minute walk test of the preliminary examination (a constituent of the Fullerton test), the patients were divided into three observation groups:

- group $\mathrm{P}_{1}$ - patients who covered the distance of more than $400 \mathrm{~m}$,

- group $\mathrm{P}_{2}$ - patients who covered the distance of more than $300 \mathrm{~m}$ but less than $400 \mathrm{~m}$,

- group $\mathrm{P}_{3}$ - patients who covered the distance of more than $200 \mathrm{~m}$, but less than $300 \mathrm{~m}$.

In addition to the systemic therapeutic exercise program, the patients from group $\mathrm{P}_{1}$ also had ergometric bicycle

Tab. I. Description of the subjects of the study, group $\mathrm{P}_{1}, n=42$

\begin{tabular}{|c|c|c|c|c|c|c|c|c|c|}
\hline & $\begin{array}{c}\text { Age } \\
\text { [years] }\end{array}$ & $\begin{array}{c}\text { Body } \\
\text { weight [kg] }\end{array}$ & $\begin{array}{l}\text { Height } \\
{[\mathrm{cm}]}\end{array}$ & $\begin{array}{c}\text { BMI } \\
{\left[\mathrm{kg} / \mathrm{m}^{2}\right]}\end{array}$ & $\begin{array}{c}\text { Dose } \\
{[\mathrm{Gy} / \mathrm{T}]}\end{array}$ & $\begin{array}{c}\text { Duration of } \\
\text { stay [day] }\end{array}$ & Diagnosis & Number & $\%$ \\
\hline Min & 48.00 & 55.00 & 164.00 & 17.76 & 40.00 & 20.00 & C34 & 42 & $100.00 \%$ \\
\hline Max & 78.00 & 106.00 & 186.00 & 34.22 & 64.00 & 44.00 & IB & 2 & $4.70 \%$ \\
\hline Mean & 61.74 & 76.44 & 173.50 & 25.40 & 57.71 & 36.81 & IIIA & 26 & $61.90 \%$ \\
\hline SD & 7.48 & 12.71 & 5.41 & 4.05 & 5.03 & 5.35 & IIIB & 14 & $33.30 \%$ \\
\hline
\end{tabular}

Tab. II. Description of the subjects of the study, group $\mathrm{P}_{2}, n=18$

\begin{tabular}{|c|c|c|c|c|c|c|c|c|c|}
\hline & $\begin{array}{c}\text { Age } \\
\text { [years] }\end{array}$ & $\begin{array}{c}\text { Body } \\
\text { weight [kg] }\end{array}$ & $\begin{array}{l}\text { Height } \\
{[\mathrm{cm}]}\end{array}$ & $\begin{array}{c}\text { BMI } \\
{\left[\mathrm{kg} / \mathrm{m}^{2}\right]}\end{array}$ & $\begin{array}{l}\text { Dose } \\
{[G y / T]}\end{array}$ & $\begin{array}{c}\text { Duration of } \\
\text { stay [day] }\end{array}$ & Diagnosis & Number & $\%$ \\
\hline Min & 53.00 & 56.00 & 157.00 & 18.08 & 40.00 & 25.00 & C34 & 18 & $100.00 \%$ \\
\hline Max & 80.00 & 100.00 & 182.00 & 39.35 & 60.00 & 44.00 & IIB & 1 & $5.60 \%$ \\
\hline Mean & 67.50 & 75.41 & 171.00 & 25.86 & 57.22 & 37.28 & $\| I I A$ & 14 & $77.80 \%$ \\
\hline SD & 8.03 & 13.06 & 6.76 & 4.77 & 5.49 & 4.57 & IIIB & 3 & $16.60 \%$ \\
\hline
\end{tabular}

Tab. III. Description of the subjects of the study, group $P_{3}, n=10$

\begin{tabular}{|c|c|c|c|c|c|c|c|c|c|}
\hline & $\begin{array}{c}\text { Age } \\
\text { [years] }\end{array}$ & $\begin{array}{c}\text { Body } \\
\text { weight [kg] }\end{array}$ & $\begin{array}{l}\text { Height } \\
{[\mathrm{cm}]}\end{array}$ & $\begin{array}{c}\text { BMI } \\
{\left[\mathrm{kg} / \mathrm{m}^{2}\right]}\end{array}$ & $\begin{array}{l}\text { Dose } \\
{[G y / T]}\end{array}$ & $\begin{array}{c}\text { Duration of } \\
\text { stay [day] }\end{array}$ & Diagnosis & Number & $\%$ \\
\hline Min & 51.00 & 55.50 & 162.00 & 19.90 & 38.00 & 29.00 & C34 & 10 & $100.00 \%$ \\
\hline Max & 78.00 & 92.00 & 176.00 & 30.49 & 60.00 & 43.00 & IB & 1 & $10.00 \%$ \\
\hline Mean & 61.50 & 70.15 & 169.30 & 24.42 & 55.20 & 36.80 & IIIA & 5 & $50.00 \%$ \\
\hline SD & 8.80 & 12.22 & 5.38 & 3.69 & 7.38 & 4.24 & IIIB & 4 & $40.00 \%$ \\
\hline
\end{tabular}


training included in their therapy. The exercise sessions took place in a gymnasium, in groups of 8-10 persons, in the late morning hours, and were delivered by skilled rehabilitators in the form of 30-minute meetings, 5 times a week. Moreover, the patients underwent ergometric bicycle training under rehabilitators' supervision 3 times a week - also in the late morning hours. The training involved 15-minute cycling with the level of intensity at 50 to $70 \%$ of maximum heart rate (HR max), which was preceded by a 3-minute warm-up; the last 2 minutes of the cycling did not include any load. Additionally, there were also regular everyday walks around the hospital park.

Group $\mathrm{P}_{2}$ pursued systemic therapeutic exercises and breathing exercises according to the plan in the late morning hours. The afternoon hours involved walks around the hospital park.

Group $\mathrm{P}_{3}$ had its rehabilitation based only on walking around the hospital park. All of the patients had the same types of test and examinations, including marking of the same parameters.

The Fullerton test (Fullerton Functional Fitness Test), designed to assess physical capability and fitness, comprises 6 trials, which allow one to make an indirect evaluation of the following parameters: strength of the upper and lower body, motor coordination, balance and aerobic endurance. The order of trials in the test is strictly specified. It begins with an attempt to flex the forearm (arm curl), then follows the "back scratch", rising from a chair, the "chair sit and reach", the " 8 feet" trial, and the 6-minute walk trial comes last. In some cases, the last trial is replaced with the 2-minute "step-in-place" - depending on participants' motor abilities $[13,14]$.

The abovementioned tests were approved by the District Board of Scientific Research Ethics. Also, the participants of the test gave their written consent after being introduced to the methods and ways of conducting the study.

The statistical hypotheses were validated by means of non-parametric tests. The differences between the groups were verified by Mann-Whitney $U$ test, while the differences between the levels of parameters of each individuals - with measurements taken both before and after the effort - were verified by the Wilcoxon test. The results of the tests were considered as valid with the level of statistical significance of $p<0.05$.

\section{Results}

In the first group, $\mathrm{P}_{1}$ (Table IV), which had ergonomic bicycle training apart from physiotherapy, the following results were noted: forearm flexion level increased from 15.02 to 15.95 times, with the improvement rate of $6.18 \%$; "back scratch" - the distance improved from $12.33 \mathrm{~cm}$ to $9.54 \mathrm{~cm}$, so the improvement rate was $22.68 \%$; rising from a chair - an improvement from 11.02 to 11.12 times, with the improvement rate of $0.86 \%$, which seems to be a rather slight change; however, the "chair sit and reach" improved from $1.60 \mathrm{~cm}$ to $0.19 \mathrm{~cm}$, which constitutes an increase of fitness by $88.06 \%$; the " 8 feet" trial involved a change from $7.21 \mathrm{~s}$ to $7.14 \mathrm{~s}$, which - at the rate of $1.02 \%$ - is also rather insignificant. The distance covered in the 6-minute walk test got shorter, from $445.24 \mathrm{~m}$ to $429.76 \mathrm{~m}$ (3.48\%), which indicates deterioration of capability of the patients from group $\mathrm{P}_{1}$ - even despite the increase of fitness and agility.

Patients from group $\mathrm{P}_{2}$ (Table $\mathrm{V}$ ) underwent physiotherapy only, with the following results: forearm flexion level increased from 10.89 to 14.44 times (32.65\%); "back scratch" - the result became worse, falling from $16.89 \mathrm{~cm}$ to $17.11 \mathrm{~cm}(1.32 \%)$; rising from a chair improved from 9.00 to 10.22 times (13.58\%); the "chair sit and reach" got worse, changing from $8.19 \mathrm{~cm}$ to $11.22 \mathrm{~cm}$ (36.95\%); there was an improvement in the " 8 feet" trial, from $9.56 \mathrm{~s}$ to $8.75 \mathrm{~s}$ (8.46\%). Similarly, the distance covered in the 6-minute walk test also got better, increasing from $311.39 \mathrm{~m}$ to $362.22 \mathrm{~m}$, with the increase rate of $16.32 \%$, proving that the patients are in better shape than before the rehabilitation.

Group $\mathrm{P}_{3}$ (Table $\mathrm{VI}$ ) had no rehabilitation exercises and the following results were noted: forearm flexion level increased from 12.00 to 13.20 times (10.00\%); "back scratch" - a deterioration, with the distance growing bigger from $14.70 \mathrm{~cm}$ to $15.50 \mathrm{~cm}$ (5.44\%); the score in rising from a chair rose from 8.00 to 8.80 times (10.00\%); the "chair sit and reach", in turn, got worse, with a fall from $14.75 \mathrm{~cm}$ to $13.00 \mathrm{~cm}(11.68 \%)$; the "8 feet" trial results got a bit worse, falling from $10.25 \mathrm{~s}$ to $9.97 \mathrm{~s}$ (2.70\%); the distance covered in the 6-minute walk test rose from $219.00 \mathrm{~m}$ to $235.00 \mathrm{~m}$

Tab. IV. Comparison of the results of the Fullerton test in group $\mathrm{P}_{1}, n=42$, before and after the therapy

\begin{tabular}{|c|c|c|c|c|c|c|c|c|c|c|c|c|}
\hline & \multicolumn{6}{|c|}{ Before therapy } & \multicolumn{6}{|c|}{ After therapy } \\
\hline & 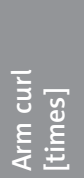 & 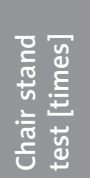 & 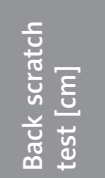 & 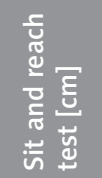 & 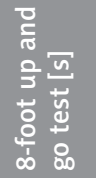 & 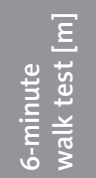 & 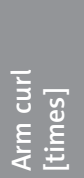 & 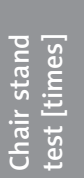 & 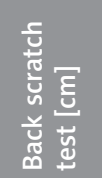 & 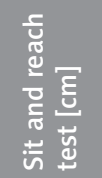 & 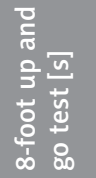 & 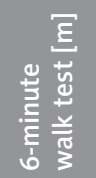 \\
\hline Mean & 15.02 & 11.02 & -12.33 & -1.60 & 7.21 & 445.24 & 15.95 & 11.12 & -9.54 & -0.19 & 7.14 & 429.76 \\
\hline Min & 9.00 & 6.00 & -39.00 & -29.00 & 4.22 & 365.00 & 5.00 & 5.00 & -37.00 & -28.00 & 4.10 & 180.00 \\
\hline Max & 30.00 & 17.00 & 9.00 & 26.00 & 11.52 & 570.00 & 33.00 & 17.00 & 10.00 & 26.00 & 11.58 & 585.00 \\
\hline SD & 3.91 & 2.48 & 12.39 & 11.32 & 1.57 & 55.60 & 4.68 & 2.86 & 11.70 & 10.56 & 1.81 & 83.45 \\
\hline$\%$ & 6.18 & 0.86 & -22.68 & -88.06 & -1.02 & -3.48 & & & & & & \\
\hline$p$ & 0.01 & 0.38 & 0.01 & 0.13 & 0.36 & 0.09 & & & & & & \\
\hline
\end{tabular}


Tab. V. Comparison of the results of the Fullerton test in group $\mathrm{P}_{2}, n=18$, before and after the therapy

\begin{tabular}{|c|c|c|c|c|c|c|c|c|c|c|c|c|}
\hline & \multicolumn{6}{|c|}{ Before therapy } & \multicolumn{6}{|c|}{ After therapy } \\
\hline & 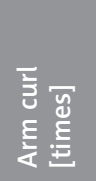 & 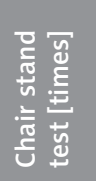 & 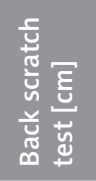 & 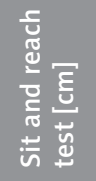 & 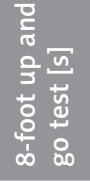 & 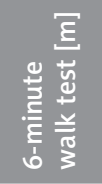 & $\begin{array}{l}\overline{\bar{z}} \bar{y} \\
\underline{\underline{y}} \\
\underline{\underline{E}}\end{array}$ & 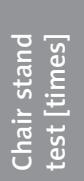 & 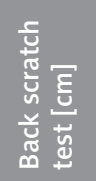 & 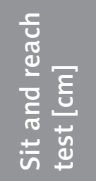 & 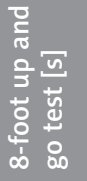 & 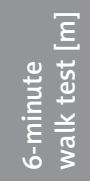 \\
\hline Mean & 10.89 & 9.00 & -16.89 & -8.19 & 9.56 & 311.39 & 14.44 & 10.22 & -17.11 & -11.22 & 8.75 & 362.22 \\
\hline Min & 7.00 & 6.00 & -32.00 & -28.00 & 6.00 & 270.00 & 8.00 & 6.00 & -36.00 & -28.00 & 5.93 & 255.00 \\
\hline Max & 18.00 & 14.00 & -4.00 & 10.00 & 13.18 & 350.00 & 21.00 & 17.00 & -3.00 & 29.00 & 11.81 & 590.00 \\
\hline SD & 2.97 & 2.38 & 8.34 & 12.23 & 1.93 & 28.89 & 3.65 & 2.82 & 8.29 & 13.51 & 1.75 & 77.71 \\
\hline$\%$ & 32.65 & 13.58 & 1.32 & 36.95 & -8.46 & 16.32 & & & & & & \\
\hline$p$ & 0.00 & 0.01 & 0.43 & 0.23 & 0.05 & 0.01 & & & & & & \\
\hline
\end{tabular}

Tab. VI. Comparison of the results of the Fullerton test in group $\mathrm{P}_{3}, n=10$, before and after the therapy

\begin{tabular}{|c|c|c|c|c|c|c|c|c|c|c|c|c|}
\hline & \multicolumn{6}{|c|}{ Before therapy } & \multicolumn{6}{|c|}{ After therapy } \\
\hline & 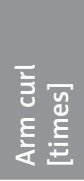 & 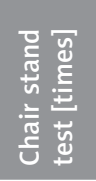 & 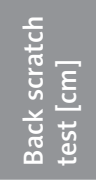 & 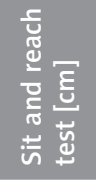 & 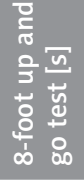 & 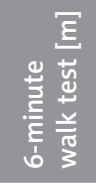 & 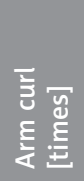 & 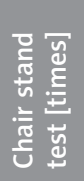 & 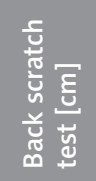 & 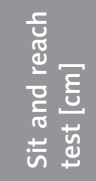 & 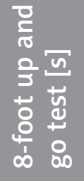 & 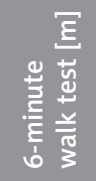 \\
\hline Mean & 12.00 & 8.00 & -14.70 & -14.75 & 10.25 & 219.00 & 13.20 & 8.80 & -15.50 & -13.00 & 9.97 & 235.00 \\
\hline Min & 6.00 & 6.00 & -31.00 & -30.00 & 5.80 & 90.00 & 7.00 & 6.00 & -29.00 & -26.00 & 6.38 & 90.00 \\
\hline Max & 19.00 & 11.00 & 3.00 & 3.50 & 15.03 & 250.00 & 17.00 & 11.00 & 8.00 & 0.00 & 15.44 & 380.00 \\
\hline SD & 3.97 & 2.21 & 13.24 & 10.83 & 3.05 & 60.64 & 3.19 & 1.55 & 14.80 & 8.72 & 3.36 & 82.33 \\
\hline$\%$ & 10.00 & 10.00 & 5.44 & -11.86 & -2.70 & 7.31 & & & & & & \\
\hline$p$ & 0.10 & 0.04 & 0.33 & 0.31 & 0.21 & 0.15 & & & & & & \\
\hline
\end{tabular}

(7.31\%), which points to the improvement of physical capability during the rehabilitation.

\section{Discussion}

Application of different methods of rehabilitation with treated groups usually leads to an improvement in functional parameters, which directly improves the quality of life [15]. Researchers point to a significant increase of overall physical activity and to a decreased fatigability after 6-week interval training using treadmill exercises with an intensity of $80 \%$ of HR max. Durak et al. [16] write about a considerable increase of muscular strength and endurance - along with a noticeable improvement of the quality of life - in a study group subject to 10 weeks of supervised aerobic and weight training, while Schwartz et al. [17] described exercises of low and moderate intensity, pursued for 8 weeks by a group of patients with chemotherapy in progress, and noted a decrease in the quality of life, an increase of fatigability and of body mass - but with a slight increase of functional efficiency. Courneya et al. [18] wrote about post-chemotherapy patients who underwent a rehabilitation program involving walking and riding a cycloergometer bicycle. They came to the conclusion that there was a relationship between the intensity of the experienced fatigue and the duration of training. Similar observations were also made by Dimeo et al. [19] by monitoring and assessing the capability and the development of fatigue among patients under chemotherapy. Pinto et al. [20], in turn, did not find any difference between the training and the untreated group in terms of fatigue and capability. Still, the training group displayed a higher level of overall vitality.

In our own presented research, there was a more or less visible improvement of most condition-assessment parameters in all of the groups participating in rehabilitation. Yet, only those groups without additional endurance training were found to display an improvement of endurance in the 6-minute walk test. Members of group $P_{1}-$ which underwent the most intensive rehabilitation - appeared to be able to shorten the distance covered in the 6-minute walk test after the rehabilitation treatment. The Fullerton test makes it possible to determine physical abilities such as the strength of lower and upper limbs, flexibility, variability or coordination, and many authors have used this test, pointing to an increase of the patients' muscle strength after application of different rehabilitation programs. Hayes et al. [21] looked into the issue of muscle strength in two groups of patients. They noted that in the group which pursued training there was a substantial improvement of muscle strength of the upper and lower parts of the body, as well as of motor coordination. In a similar way, Mello et al. [22] compared the results of their untreated and treated groups and observed an increase of muscle strength among 
the members of the treated group. Segal et al. [23] arrived at corresponding conclusions, pointing to a bigger increase of physical functional capabilities of the patients from the treated group compared to those from the untreated one. Dimeo et al. [15] also found an increase of the maximum functional abilities, as well as a decrease of the intensity of pain, among the members of the group pursuing treadmill training - unlike among those in the non-training group.

This study also showed that after application of rehabilitation treatment there followed positive functional changes involving an increase of muscle strength of upper limbs in group $\mathrm{P}_{1}$ by $6.18 \%(p=0.01)$ and an increase of upper limb flexibility in the same group by $22.68 \%(p=0.01)$. However, there were no changes in the strength of lower limbs in this group - with a simultaneous decrease of the length of the covered distance by $3.48 \%$. As for group $\mathrm{P}_{2}$, in turn, the strength of upper limbs increased by $32.65 \%$ $(p=0.00)$, the strength of lower limbs by $13.58 \%(p=0.01)$, the flexibility of upper limbs grew by $1.32 \%$ and of lower limbs by $36.95 \%$, and the covered distance went up by $16.32 \%$ ( $p=0.01)$. The parameter of strength of both upper and lower limbs, as well as the covered distance in group $\mathrm{P}_{3}$, improved, too. What is more, Burnham and Wilcox [24] also reported an increase of flexibility of the lower part of the body after introduction of therapeutic training.

\section{Conclusions}

The results obtained in the study lead to the following conclusions:

1. Intensive training for patients with lung cancer led to adverse changes of capability and physical fitness of the members of the study group.

2. A moderate rehabilitation program based on systemic therapeutic training - without endurance training - improved the fitness and capability of the patients after the rehabilitation treatment finished.

3. Physical therapy without any endurance training may be recommended as a dedicated method of rehabilitation for this group of patients.

\section{References}

1. Bray F, Guilloux A, Sankila R, Parkin DM. Practial implication of imposing a new world standard population. Cancer Causes Control 2002; 13: 175-182.

2. Parkin DM, Bray FI, Devesa SS. Cancer burden in the year 2000. The global picture. Eur J Cancer 2001; 37 Suppl 8: S4-S66.

3. Tyczyński JE, Bray F, Parkin DM. Lung cancer in Europe in 2001: epidemiology, prevention, and early detection. Lancet Oncol 2003; 4: 45-55.
4. Wojciechowska U, Didkowska J, Tarkowski W, Katoński W. Nowotwory złośliwe w Polsce w 2002 roku. Centrum Onkologii, Warszawa 2004.

5. Hyatt RE. Expiratory flow limitation. J Appl Physiol 1983; 55: 1-7.

6. Pride NB, Macklem PT. Lung mechanics in disease. In: Fishman AP (ed.). Handbook of Physiology. American Physiology Society, Oxford University Press, Bethesda 2001; 659-692.

7. Aliverti A, Stevenson N, Dellaca RL, Lo MA, Pedotti A, Calverley PM. Regional chest wall volumes during exercise in chronic obstructive pulmonary disease. Thorax 2004; 59: 210-216.

8. Diaz O, Villafranca C, Ghezzo H, Borzone G, Leiva A, Milic-Emil J, Lisboa C. Role of inspiratory capacity on exercise tolerance in COPD patients with and without tidal expiratory flow limitation at rest. Eur Respir J 2000; 16: 269-275.

9. Voelkel NF, Tuder RM. Hypoxiainduced pulmonary vascular remodeling: a model for what human disease? J Clin Invest 2000; 106: 733-738.

10. Chetty KG, Brown SE, Light EW. Improved exercise tolerance of the polycythemic lung patient following phlebotomy. Am J Med 1983; 74: 415-420.

11. Butler J, Schrijen F, Henriguez A, Polu JM, Albert RK. Cause of raised wedge pressure on exercise in chronic obstructive pulmonary disease. Am Rev Respir Dis 1988; 138: 350-354.

12. Maltais F, Jobin J, Sullivan MJ, Bernard S, Whittom F, Killian KJ, Desmeules M, Belanger M, LeBlanc P. Metabolic and hemodynamic responses of lower limb during exercise in patients with COPD. J Appl Physiol 1998; 84: 1573-1580.

13. Jones J, Rikli R. Senior Fitness Testing. American Fitness 2001; 19: 6-9.

14. Różańska-Kirschke A, Kocur P, Wilk M, Dylewicz P. Test Fullerton jako miernik sprawności fizycznej osób starszych. Rehabilitacja Medyczna 2006; 10: 15-19.

15. Dimeo FC, Tilmann MH, Bertz H, Kanz L, Mertelsmunn R, Keul J. Aerobic exercise in the treatment of cancer patients after high dose chemotherapy and autologous peripheral steam cell transplantation. Cancer 1997; 79: 1717-1722.

16. Durak EP, Lilly PC, Hackworth JL. Physical and psychological response to exercise in cancer patients. A two year follow-up survey with prostrate, leukemia and general carcinoma. J Exerc Physiol 1999; 2: 1-9.

17. Schwartz AL. Fatigue mediates the effects of exercise on quality of life. Qual Life Res 1999; 8: 529-538.

18. Courneya KS, Keats MR, Turner RA. Physical exercise and quality of life in cancer patients following high dose chemotherapy and autologous bone marrow transplantation. Psychooncology 2000; 9: 127-136.

19. Dimeo F, Stieglitz RD, Novelli-Fischer U, Fetscher S, Mertelsmann R, Keul J. Correlation between physical performance and fatigue in cancer patients. Ann Oncol 1997; 8: 1251-1255.

20. Pinto BM, Maruyama NC, Engebretson TO, Thebarge RW. Participation in exercise, mood, and coping in survivors of early stage breast cancer. J Psychosoc Oncol 1998; 16: 45-59.

21. Hayes S, Davies PSW, Pareker T, Bashford J. Total energy expenditure and body composition changes following peripheral blood stem cell transplantation and participation in an exercise programme. Bone Marrow Transplant 2003; 31: 331-338.

22. Mello M, Tanaka C, Dulley FL. Effects of an exercise program on muscle performance in patients undergoing allogeneic bone marrow transplantations. Bone Marrow Transplant 2003; 32: 723-728.

23. Segal R, Evans W, Johanson D, Smith J, Colletta S, Gayton J, Woodard S, Wells G, Reid R. Structured exercise improves physical functioning in women with stages I and II breast cancer: results of a randomized controlled trial. J Clin Oncol 2001; 19: 657-665.

24. Burnham TR, Wilcox A. Effects of exercise on psychological and psychological variables in cancer survivors. Med Sci Sports Exerc 2002; 34: 1863-1867. 